\title{
Development of Ready-to-Eat Color Rice Product Enriched With Natural Amino Acids
}

\author{
Prajongwate Satmalee ${ }^{1}$, Vipa Surojanametakul ${ }^{1}$, Ngamjit Lowithun ${ }^{1}$, Rattanawan Mungkung ${ }^{2}$ \\ \& Sarocha Dangsiri ${ }^{3}$ \\ ${ }^{1}$ Institute of Food Research and Product Development, Kasetsart University, Bangkok, Thailand \\ ${ }^{2}$ Center of Excellence on Environmental Strategy for GREEN Business, Kasetsart University, Bangkok, \\ Thailand \\ ${ }^{3}$ Department of Environmental Technology and Management, Faculty of Environment, Kasetsart University, \\ Bangkok, Thailand \\ Correspondence: Prajongwate Satmalee, Institute of Food Research and Product Development, Kasetsart \\ University, Bangkok 10900, Thailand. Tel: 660-294-286-2935. E-mail: ifrpws@ku.ac.th
}

Received: May 8, 2019

doi:10.5539/jas.v11n13p56
Accepted: June 24, 2019 Online Published: August 15, 2019

URL: https://doi.org/10.5539/jas.v11n13p56

\begin{abstract}
A meat-free diet and the aging society cause some of the health problems. One of that was the deficiency of some essential amino acid in the diets. Riceberry has recently been developed in Thailand. This new variety of colored rice has a dark purple seed coat containing anthocyanin which acts as an antioxidant. Similar to normal rice, riceberry lacks lysine which plays an important role in maintaining body systems through hormone release and muscle mass maintenance. To enrich ready-to-eat rice products, red bean was added as a natural amino acid source. This formulated product had higher protein and ash content, while energy, fat and carbohydrate content were not different from the control. The essential amino acid profile of the product was complete and product shelf life was 6 months with an unchanged texture. Anthocyanin and antioxidant capacity of the product decreased with storage time. This product suited a wide range of consumers and was convenient for modern lifestyles that demand healthy, ready-to-eat foodstuffs.
\end{abstract}

Keywords: riceberry, colored rice, red bean, lysine

\section{Introduction}

Demand for meat-free diets is increasing and this has resulted in emerging health problems through lack of proteins. Hypoalbuminemia results from replacement of cow milk by rice milk (Massa et al., 2001) as a symptom caused by protein malnutrition (Steele, Yokum, \& Armstrong, 1998) which and is related to heart failure (Filippatos et al., 2011). Apart of the lifestyle changing that causes the malnutrition, the aging is also the cause of undernutrition. Lamy, Mojon, Kalykakis, Legrand, and Butx-Jorgensen (1999) reported that oral problems resulted in eating difficulties which affected health conditions in the elderly (Pirlich \& Lochs, 2001).

Rice is the staple carbohydrate source of Asian cuisine but unfortunately, it lacks essential amino acids, particularly lysine (Sotelo, Hernandez, Montalvo, \& Sousa, 1994; Moonggnarm \& Saetung, 2010). It is well known that lack of lysine leads to kwashiorkor in infants (Albanese, Higgons, Hyde, \& Orto, 1956) and retards mental and physical development in children (Galili \& Amir, 2013). Furthermore, in adults and the elderly, lysine also plays an important role in maintaining body systems such as growth hormone release (Isidori, Lo, Monaco, \& Cappa, 1981) and muscle mass increase in the elderly (Fuller et al., 2011). To solve lysine deficiency in rice, new genetically engineered rice cultivars (Wang \& Galili, 2016) were introduced but some consumers had doubts about their safety. Another option for improving rice amino acid profiles is by adding other sources of lysine plant protein. Bressani and Valiente (1962) suggested that black bean could supplement polished rice with lysine at low cost (Bressani, 2010).

Following the health and wellness trend, unpolished rice is now preferred by consumers over polished rice due to the health benefits of fiber, while colored rice has gained increasing interest. Riceberry has become the popularly consumed rice in Thailand as this variety contains micronutrients, particularly anthocyanins, which are known for their antioxidant capacity. Unpolished rice takes longer to cook because the bran layer retards water 
penetration into the grain (Mohapatra \& Bal, 2006). This phenomenon also occurs in red bean cooking (Zamindar, Baghekhandan, Nasirpour, \& Sheikhzeinoddin, 2013). To solve this problem, a longer soaking time before cooking resulted in a softer texture (Tian et al., 2014; Meng et al., 2018). Pretreatment of rice and red bean also affects product eating quality. Rewthong, Soponronnarit, Taechapairoj, Tungtrakul, and Prachayawarakorn (2011) and Syafutri, Pratama, Syaiful, and Faizal (2016) reported that blanching or boiling resulted in a harder texture of cooked rice than steaming or using a rice cooker. Moreover, heat treatment was also efficient in beany flavor removal (Yuan, Chang, Liu, \& Xu, 2008). Here, ready-to-eat brown rice products were developed using the riceberry variety enriched with red kidney bean to complement the amino acid profile. Moreover, product shelf life was evaluated based on textural and antioxidant properties.

\section{Method}

\subsection{Material}

Riceberry, purple-black color Thai brown rice, was purchased from the Rice Science Center Kasetsart University, while red bean was purchased from a local market.

\subsection{Rice and Red Bean Preparation}

Rice and red bean were separately soaked in $50{ }^{\circ} \mathrm{C}$ water for $4 \mathrm{hr}$ to obtain moisture contents at approximately 30 and $50 \%$, respectively. Then, the soaked rice was steamed for $15 \mathrm{~min}$ while the red bean was pressure cooked at 8 psi for $15 \mathrm{~min}$. The precooked rice and red bean were kept in closed containers until required for further experiments.

\subsection{Effect of Phosphate Salt}

Starch products undergo retrogradation during storage, resulting in increased hardness or stiffness of the products. To retard this phenomenon, phosphate salts were used to increase water absorption in the products and slow down starch retrogradation. Phosphate salt concentration in the sample was $0.15 \%$ by wt. Textures of riceberry and red bean were analyzed to compare with the control sample which was not added with phosphate salt.

\subsection{Preparation of Ready to Eat Rice Mixed With Red Bean}

Precooked rice $100 \mathrm{~g}$ was mixed with $50 \mathrm{~g}$ precooked red bean in a retort pouch, then $20 \mathrm{ml}$ of $0.3 \%$ salt water was added before sealing and sterilizing using a water spray retort (Model: ARS-100/20; HISAKA, Japan). The sterilized temperature was $118{ }^{\circ} \mathrm{C}$ with processing time of $40 \mathrm{~min}$. Proximate analysis of the samples was determined according to AOAC (2006).

\subsection{Texture Analysis}

Changes of textural properties of riceberry and red bean during 6 months of storage at ambient temperature were determined separately using a Texture Analyzer (TA-Tx2i, Stable Micro, UK) equipped with a $25 \mathrm{~mm}$ diameter cylinder probe $(\mathrm{P} / 25)$. Test speed was $1 \mathrm{~mm} / \mathrm{sec}$ and pressed to $60 \%$ strain. Hardness of the samples was analyzed.

\subsection{Anthocyanin and Antioxidant Capacities}

The $5 \mathrm{~g}$ of sample was treated with $50 \mathrm{ml}$ of $1 \mathrm{mM}$ citric acid in $80 \%$ ethanol for $3 \mathrm{hr}$. Clear supernatant was then collected and kept at $-20{ }^{\circ} \mathrm{C}$ until analyzed for its anthocyanin content (Pedro, Granato, \& Rosso, 2016). Moreover, antioxidant capacities were determined for total phenolic content (Kaur \& Kapoor, 2002), DPPH (Brand-Williams, Cuvelier, \& Berset, 1995) and FRAP (Benzie \& Strain, 1999).

\subsection{Amino Acid Profile of the Product}

The amino acid profile of the enriched product was analyzed using HPLC according to the method of Herbert, Barros, Ratola, and Alves (2000).

\subsection{Data Analysis}

All experiments were carried out in triplicate. Results were reported as average values with standard deviations. Analysis of variance (ANOVA) and Duncan's multiple range test (DMRT) at $p=0.05$ were used to determine differences between treatments using SPSS version 12.0.

\section{Results and Discussion}

\subsection{Effect of Phosphate Salt}

The rice and red bean were precooked by steeping in warm water at $50{ }^{\circ} \mathrm{C}$ and pressure cooked. This process not only precooked the seeds but also improved cooking and eating quality of the rice (Park, Chae, \& Yoon, 2009). 
Cooked or gelatinized rice products undergo natural starch reconstruction or retrogradation. This results in changes of physical properties, especially texture which becomes harder and firmer due to loss of water in the gel matrix.

The most common method to retard the retrogradation process is by adding food additives. Among these, phosphate salt is commonly selected as it is cheap, efficient and recognized as safe among food manufacturers. Additionally, phosphate salt increases water binding capacity in many products including rice (Chang \& Regenstein, 1997; Singh, Kaur, Singh, \& Sekhon, 1999). Lee, Han, and Rhee (2002) found that sodium phosphate salt retarded the retrogradation process. Here, riceberry and red bean with phosphate salt added had a softer texture (Table 1). This result concurred with Wang, Hou, Hsu, and Zhou (2011) who reported that adding phosphate salt yielded softer texture in non-fried instant noodle.

Table 1. Texture of control and phosphate salt added riceberry and red bean kept in ambient temperature for 24 $\mathrm{hr}$

\begin{tabular}{lll}
\hline Sample & & Hardness $(\mathrm{g})$ \\
\hline Riceberry & Control & $3,367.54 \pm 483.86 \mathrm{~b}$ \\
& Phosphate added & $2,650.79 \pm 563.08 \mathrm{a}$ \\
\hline Red bean & Control & $3,762.71 \pm 152.89 \mathrm{a}$ \\
& Phosphate added & $3,512.40 \pm 87.57 \mathrm{a}$
\end{tabular}

Note. Different letters in the same column of each raw material indicate statistical differences $(p<0.05)$.

\subsection{Nutrition Value of Products}

Nutrient contents of control and the enriched samples were determined. Overall energy and energy from fat were similar (Table 2). Fat and carbohydrate contents were slightly lower than control, while ash was slightly higher in enriched samples. Protein content of enriched samples was significantly higher than control due to added red bean. Results concurred with Rodríguez-Bürger, Mason, and Nielsen (1998) who reported that addition of black bean increased protein and ash content compared to rice alone. Legumes contain protein at around $24-26 \%$ (Bressani, 2010), while protein content in rice is about 7\% (Shih, 2003). Therefore, the combination of rice and legume altered the protein content in rice products.

Table 2. Nutrition values of control and enriched samples

\begin{tabular}{lll}
\hline Detail & Control & Enriched sample \\
\hline Total energy $(\mathrm{kcal} / 100 \mathrm{~g})$ & $210.87 \pm 7.57 \mathrm{a}$ & $207.53 \pm 13.00 \mathrm{a}$ \\
Energy from fat $(\mathrm{kcal} / 100 \mathrm{~g})$ & $20.25 \pm 0.13 \mathrm{a}$ & $19.49 \pm 1.46 \mathrm{a}$ \\
Moisture (\%) & $49.19 \pm 1.89 \mathrm{a}$ & $49.79 \pm 2.94 \mathrm{a}$ \\
Carbohydrate $(\%)$ & $42.73 \pm 1.66 \mathrm{a}$ & $41.23 \pm 2.88 \mathrm{a}$ \\
Protein $(\%)$ & $4.93 \pm 0.20 \mathrm{a}$ & $5.79 \pm 0.01 \mathrm{~b}$ \\
Fat $(\%)$ & $2.25 \pm 0.01 \mathrm{a}$ & $2.17 \pm 0.16 \mathrm{a}$ \\
Ash $(\%)$ & $0.91 \pm 0.01 \mathrm{a}$ & $1.04 \pm 0.11 \mathrm{a}$ \\
\hline
\end{tabular}

Note. Different letters in the same row indicate statistical differences $(p<0.05)$.

\subsection{Essential Amino Acid Content}

Development of food blends vegetable protein to obtain the essential amino acid pattern of animal protein. A mixture of cereal grains and legume is a commonly used example. The legume provides lysine amino acid which is lacking in cereal grains (Bressani, 2010). Essential amino acid contents in the enriched products are shown in Table 3. Rice is a cereal crop that normally lacks lysine. Saikusa, Horino, and Mori (1994) reported that lysine content in brown rice kernels was $0.7 \mathrm{mg} / 100 \mathrm{~g}$, while lysine in bean was $1.96 \mathrm{~g} / 100 \mathrm{~g}$ dry matter and lysine content increased to $2.12 \mathrm{~g} / 100 \mathrm{~g}$ when cooked (Rodríguez-Bürger et al., 1998). Red bean was reported as high in lysine content, and the cooking method did not affect the amount of lysine in cooked beans (Audu \& Aremu, 2011). Our results suggested that adding red bean increased amino acid content in ready to eat rice products. 
Table 3. Essential amino acid content in enriched samples

\begin{tabular}{lll}
\hline Amino acid & Content $(\mathrm{mg} / 100 \mathrm{~g}$ as eaten $)$ & Content $(\mathrm{mg} / 100 \mathrm{~g}$ dry basis $)$ \\
\hline Alanine & 254 & 505.88 \\
Arginine & 345 & 687.11 \\
Aspartic acid & 350 & 697.07 \\
Cystine & 126 & 250.95 \\
Glutamic acid & 702 & $1,398.13$ \\
Glycine & 305 & 607.45 \\
Histidine & 142 & 282.81 \\
Isoleucine & 268 & 533.76 \\
Leucine & 400 & 796.65 \\
Lysine & 141 & 280.82 \\
Methionine & 99 & 197.17 \\
Phenylalanine & 324 & 645.29 \\
Proline & 65 & 129.46 \\
Serine & 294 & 585.54 \\
Threonine & 203 & 404.30 \\
Tryptophan & 493 & 981.88 \\
Tyrosine & 163 & 324.64 \\
Valine & 265 & 527.78 \\
\hline
\end{tabular}

\subsection{Shelf life of the Enriched Product}

\subsubsection{Texture Analysis}

Product texture change during storage for 6 months at room temperature was monitored by a texture analyzer. Riceberry and red bean hardness slightly increased with longer storage time (Table 4). Grain hardness increased as the result of starch retrogradation (Perdon, Siebenmorgen, Buescher, \& Gbur, 1999; Kingcam, Devahastin, \& Chiewchan, 2008). C. E. Park, Y. S. Kim, K. J. Park, and B. K. Kim (2012) stated that increasing grain hardness related to loss of moisture from starch gel during storage. Moreover, change in hardness of rice and red bean was not greatly affected by storage time due to the contribution of the outer layer of the grain (Mariotti, Sinelli, Catenacci, Pagani, \& Lucisano, 2009) that could prevent the moisture loss which would retard the texture changes.

Table 4. Texture of riceberry and red bean in product stored for 6 months

\begin{tabular}{lll}
\hline Storage time (month) & Riceberry Hardness $(\mathrm{g})$ & Red bean Hardness $(\mathrm{g})$ \\
\hline 0 & $3,677.88 \pm 717.78 \mathrm{ab}$ & $5,763.71 \pm 301.63 \mathrm{a}$ \\
2 & $3,347.83 \pm 513.80 \mathrm{a}$ & $6,558.64 \pm 755.53 \mathrm{~b}$ \\
4 & $3,595.26 \pm 530.67 \mathrm{ab}$ & $5,934.86 \pm 215.11 \mathrm{a}$ \\
6 & $3,789.64 \pm 231.56 \mathrm{~b}$ & $6,339.05 \pm 317.47 \mathrm{ab}$ \\
\hline
\end{tabular}

Note. Different letters in the same column indicate statistical differences $(p<0.05)$.

\subsubsection{Anthocyanin and Antioxidant Capacities}

Anthocyanin content in the products significantly decreased after processing and then remained constant during storage time (Table 5). Because of their highly reactive nature, anthocyanins readily degrade or react with other constituents in the media, while water addition resulted in the formation of colorless chalcone (Htwe et al., 2010) or brown colored compounds. Moreover, anthocyanin decomposed during thermal processing (Walter et al., 2013), resulting in a color change. Min, McClung, and Chen. (2014) reported that anthocyanin decreased by $78 \%$ after wet cooking due to heat decomposition and leaching of water-soluble anthocyanin. In addition, anthocyanin degraded with storage time (Patras, Brunton, O'Donnell, \& Tiwari, 2010) due to oxidation (Rhim, 2002) and phenolic complexation (Reed, Krueger, \& Vestling, 2005). 
Phenolic content in the product also decreased with storage time (Table 6) and $70 \%$ of phenolic compounds were lost when the product was kept for 6 months. Wallace and Guisti (2008) reported that phenolic compounds stored in berry added yogurt reduced. Reduction of phenolic compounds was influenced by oxidation (Abramovic, Butinar, \& Nikoliê, 2007). Phenolic compounds were affected by heating processes less than anthocyanins since they were more thermally stable and less water-soluble (Min et al., 2014).

Table 5. Anthocyanin content in product stored for 6 months

\begin{tabular}{ll}
\hline Storage time (month) & Anthocyanin content $(\mathrm{mg} / \mathrm{g} \mathrm{db})$ \\
\hline Raw material & $69.36 \pm 6.31 \mathrm{~b}$ \\
0 & $26.37 \pm 2.32 \mathrm{a}$ \\
3 & $23.84 \pm 1.10 \mathrm{a}$ \\
6 & $23.67 \pm 0.31 \mathrm{a}$ \\
\hline
\end{tabular}

Note. Different letters in the same column indicate statistical differences $(p<0.05)$.

Antioxidant capacity of the stored product was determined for DPPH and FRAP with results shown in Table 6. Storage decreased antioxidant capacity of the product. Our results concurred with Gujral, Angurala, Sharma, and Singh (2011) who suggested that antioxidant activity of pressure cooked pulse was lower than raw pulse. Antioxidant activity was reduced by antioxidants leaching to water with thermal decomposition (Xu \& Chang, 2007). At longer storage time, antioxidant capacity decreased, related to the phenolic content in the sample (Kalt, McDonald, \& Donner, 2000; Kim, Jeong, \& Lee, 2003; Piljac-Žegarac, Valek, Martinez, \& Belščak, 2009). Brownmiller, Howard, and Prior (2008) indicated that this was the result of anthocyanin decomposition.

Table 6. Phenolic content and antioxidant capacity in product stored for 6 months

\begin{tabular}{llll}
\hline Storage time (month) & Phenolic content $(\mu \mathrm{g} / \mathrm{g} \mathrm{db})$ & DPPH $(\mu \mathrm{g}$ gallic eq $/ \mathrm{g} \mathrm{db})$ & FRAP $(\mu \mathrm{g}$ trolox eq $/ \mathrm{g} \mathrm{db})$ \\
\hline Raw material & $260.57 \pm 6.03 \mathrm{c}$ & $440.30 \pm 4.24 \mathrm{~d}$ & $520.00 \pm 10.94 \mathrm{c}$ \\
0 & $258.02 \pm 3.85 \mathrm{c}$ & $158.89 \pm 1.10 \mathrm{~b}$ & $160.69 \pm 17.12 \mathrm{~b}$ \\
3 & $251.12 \pm 1.80 \mathrm{~b}$ & $163.38 \pm 2.31 \mathrm{c}$ & $145.86 \pm 1.19 \mathrm{ab}$ \\
6 & $184.53 \pm 2.15 \mathrm{a}$ & $144.76 \pm 1.55 \mathrm{a}$ & $133.26 \pm 2.83 \mathrm{a}$ \\
\hline
\end{tabular}

Note. Different letters in the same column indicate statistical differences $(p<0.05)$.

\section{Conclusions}

An upsurge in the popularity of meat-free diets and an aging society have resulted in many health problems because of essential amino acid deficiency. Rice is the main source of carbohydrate in Asian cuisine and a popular new variety of colored rice has entered the Thai market, namely riceberry that contains anthocyanin which acts as an antioxidant. However, similar to normal rice, riceberry lacks lysine. To enrich the rice product, red bean which is rich in minerals was added to complete the amino acid profile. The formulated product of mixing riceberry and red bean was high in protein and ash. The essential amino acid profile of the product was completed. Shelf life was 6 months with unchanged textural properties but anthocyanin and antioxidant capacities of the product decreased with storage time. This product is popular with a wide group of consumers and convenient for fast-paced lifestyles that demand healthy products with minimal preparation time.

\section{References}

Abramovic, H., Butinar, B., \& Nikoliê, V. (2007). Changes occurring in phenolic content, tocopherol composition and oxidative stability of Camelina sativa oil during storage. Food Chemistry, 104, 903-909. https://doi.org/10.1016/j.foodchem.2006.12.044

Albanese, A. A., Higgons, R. D., Hyde, G. M., \& Orto, L. (1956). Lysine and tryptophan content of proteins and their utilization for human growth. The American Journal of Clinical Nutrition, 4, 161-168. https://doi.org/ 10.1093/ajen/4.2.161

Association of Official Analytical Chemists. (2006). Official methods of analysis of AOAC International (18th ed.). Arlington, TX. 
Audu, S. S., \& Aremu, M. O. (2011). Effect of processing on chemical composition of red kidney bean (Phaseolus vulgaris L.) flour. Pakistan Journal of Nutrition, 10, 1069-1075. https://doi.org/10.3923/ pjn.2011.1069.1075

Benzie, I. F. F., \& Strain, J. J. (1999). Ferric reducing/antioxidant power assay: Direct measure of total antioxidant activity of biological fluids and modified version of simultaneous measurement of total antioxidant power and ascorbic acid concentration. Method in Enzymology, 299, 15-27. https://doi.org/ 10.1016/s0076-6879 (99)99005-5

Brand-Williams, W., Cuvelier, M. E., \& Berset, C. (1995). Use of a free radical method to evaluate antioxidant activity. LWT-Food Science and Technology, 28, 25-30. https://doi.org/10.1016/s0023-6438(95)80008-5

Bressani, R., \& Valiente, A. T. (1962). All-vegetable protein mixtures for human feeding VII. Protein complementation between polished rice and cooked black beans. Journal of Food Science, 27, 401-406. https://doi.org/10.1111/j.1365-2621.1962.tb00115.x

Bressani, R. (2010). INCAP studies of vegetable proteins for human consumption. Food and Nutrition Bulletin, 31, 95-110. https://doi.org/10.1177/156482651003100110

Brownmiller, C., Howard, L. R., \& Prior, R. L. (2008). Processing and storage effects on monomeric anthocyanins, percent polymeric color, and antioxidant capacity of processed blueberry. Journal of Food Science, 73, H72-H79. https://doi.org/10.1111/j.1750-3841.2008.00761.x

Chang, C. C., \& Regenstein, J. M. (1997). Water uptake, protein solubility, and protein changes of cod mince stored on ice as affected by polyphosphates. Journal of Food Science, 62, 305-309. https://doi.org/ 10.1111/j.1365-2621.1997.tb03990.x

Fillippatos, G. S., Desai, R. V., Ahmed, M. I., Fonarow, G. C., Love, T. E., Aban, I. B., ... Ahmed, A. (2011). Hypoalbuminaemia and incident heart failure in older adults. European Journal of Heart Failure, 13, 1078-1986. https://doi.org/10.1093/eurjhf/hfr088

Fuller, J. C., Baier, S., Flakoll, P., Nissen, S. L., Abumrad, N. N., \& Rathmacher, J. A. (2011). Vitamin D status affects strength gains in older adults supplemented with a combination of $\beta$-Hydroxy- $\beta$-Methylbutyrate, Arginine and Lysine. Journal of Parenteral and Enteral Nutrition, 35, 757-762. https://doi.org/10.1177/ 0148607111413903

Galili, G., \& Amir, R. (2013). Fortifying plants with the essential amino acid lysine and methionine to improve nutritional quality. Plant Biotechnology Journal, 11, 211-222. https://doi.org/10.1111/pbi.12025

Gujral, H. S., Angurala, M., Sharma, P., \& Singh, J. (2011). Phenolic content and antioxidant activity of germinated and cooked pulses. International Journal of Food Properties, 14, 1366-1374. https://doi.org/ 10.1080/10942911003672167

Herbert, P., Barros, P., Ratola, N., \& Alves, A. (2000). HPLC determination of amino acids in must and port wine using OPA/FMOC derivatives. Journal of Food Science, 65, 1130-1133. https://doi.org/ 10.1111/j.1365-2621.2000.tb10251.x

Htwe, N. N., Srilaong, V., Tanprasert, K., Tongchitpakdee, S., Kanlayanarat, S., \& Uthairatanakij, A. (2010). Effects of storage time and temperature on radical scavenging activities and bioactive compounds in colored rice varieties. Journal of Food, Agriculture \& Environment, 8, 26-31. https://doi.org/ 10.1234/4.2010.2946

Isidori, A., Lo Monaco, A., \& Cappa, M. (1981). A study of growth hormone release in man after oral administration of amino acids. Current Medical Research and Opinion, 7, 475-481. https://doi.org/ $10.1185 / 03007998109114287$

Kalt, W., McDonald, J. E., \& Donner, H. (2000). Anthocyanins, phenolics and antioxidant capacity of processed Lowbush blueberry products. Journal of Food Science, 65, 390-393. https://doi.org/10.1111/ j.1365-2621.2000.tb16013.x

Kaur, C., \& Kapoor, H. C. (2002). Anti-oxidant activity and total phenolic content of some Asian vegetables. International Journal of Food Science and Technology, 37, 153-161. https://doi.org/10.1046/ j.1365-2621.2002.00552.x

Kim, D. O., Jeong, S. W., \& Lee, C. Y. (2003). Antioxidant capacity of phenolic phytochemicals from various cultivars of plums. Food Chemistry, 81, 321-326. https://doi.org/10.1016/S0308-8146(02)00423-5 
Kingcam, R., Devahastin, S., \& Chiewchan, N. (2008). Effect of starch retrogradation on texture of potato chips produced by low-pressure superheated stream drying. Journal of Food Engineering, 89, 72-79. https://doi.org/10.1016/j.jfoodeng.2008.04.008

Lamy M., Mojon, P., Kalykakis, G., Legrand, R., \& Butx-Jorgensen, E. (1999). Oral status and nutrition in the institutionalized elderly. Journal of Dentistry, 27, 443-448. https://doi.org/10.1016/S0300-5712(99) 0002-0

Lee, S. W., Han, S. H., \& Rhee, C. (2002). Effects of various salts and emulsifiers on retrogradation rate of rice starch gel. Food Science and Biotechnology, 11, 48-54.

Mariotti, M., Sinelli, N., Catenacci, F., Pagani, M. A., \& Lucisano, M. (2009). Retrogradation behavior of milled and brown rice pasted during ageing. Journal of Cereal Science, 49, 171-177. https://doi.org/10.1016/ j.jcs.2008.09.005

Massa, G., Vanoppen, A., Gillis, P., Aerssens, P., Alliet, P., \& Raes, M. (2001). Protein malnutrition due to replacement of milk by rice drink. European Journal of Pediatrics, 160, 382-384. https://doi.org/10.1007/ s004310100746

Meng, L., Zhang, W., Wu, Z., Hui, A., Gao, H., Chen, P., \& He, Y. (2018). Effect of pressure-soaking treatments on texture and retrogradation properties of black rice. LWT-Food Science and Technology, 93, 485-490. https://doi.org/10.1016/j.lwt.2018.03.079

Min, B., McClung, A., \& Chen, M.-H. (2014). Effects of hydrothermal processes on antioxidants in brown, purple and red bran whole grain rice (Oryza sativa L.). Food Chemistry, 159, 106-115. https://doi.org/ 10.1016/j.foodchem.2014.02.164

Mohapatra, D., \& Bal, S. (2006). Cooking quality and instrumental textural attributes of cooked rice for different milling fractions. Journal of Food Engineering, 73, 253-259. https://doi.org/10.1016/j.jfoodeng.2005.01. 028

Moonggnarm, A., \& Saetung, N. (2010). Composition of chemical compositions and bioactive compounds of germinated rough rice and brown rice. Food Chemistry, 122, 782-788. https://doi.org/10.1016/ j.foodchem.2010.03.053

Park, J. W., Chae, S. H., \& Yoon, S. (2009). The effects of steeping and cooking pressure on qualities of cooked brown rice. Journal of the Korean Society of Food Culture, 24, 69-76.

Park, C. E., Kim, Y. S., Park, K. J., \& Kim, B. K. (2012). Changes in physicochemical characteristics of rice during storage at different temperatures. Journal of Stored Products Research, 48, 25-29. https://doi.org/ 10.1016/j.jspr.2011.08.005

Patras, A., Brunton, N. P., O’Donnell, C., \& Tiwari, B. K. (2010). Effect of thermal processing on anthocyanin stability in foods; mechanisms and kinetics of degradation. Trends in Food Science \& Technology, 21, 3-11. https://doi.org/10.1016/j.tifs.2009.07.004

Pedro, A. C., Granato, D., \& Rosso, N.D. (2016). Extraction of anthocyanins and polyphenols from black rice (Oryza sativa L.) by modeling and assessing their reversibility and stability. Food Chemistry, 191, 12-20. https://doi.org/10.1016/j.foodchem.2015.02.045

Perdon, A. A., Siebenmorgen, T. J., Buescher, R. W., \& Gbur, E. E. (1999). Starch retrogradation and texture of cooked milled rice during storage. Journal of Food Science, 64, 828-832. https://doi.org/10.1111/ j.1365-2621.1999.tb15921.x

Piljac-Žegarac, J., Valek, L., Martinez, S., \& Belščak, A. (2009). Fluctuations in the phenolic content and antioxidant capacity of dark fruit juices in refrigerated storage. Food Chemistry, 113, 394-400. https://doi.org/10.1016/j.foodchem.2008.07.048

Pirlich, M., \& Lochs, H. (2001). Nutrition in the elderly. Best Practice \& Research Clinical Gastroenterology, 15, 869-884. https://doi.org/10.1053/bega.2001.0246

Reed, J. D., Krueger, C. G., \& Vestling, M. M. (2005). MALDI-TOF mass spectrometry of oligomeric food polyphenols. Phytochemistry, 66, 2248-2263. https://doi.org/10.1016/j.phytochem.2005.05.015

Rewthong, O., Soponronnarit, S., Taechapairoj, C., Tungtrakul, P., \& Prachayawarakorn, S. (2011). Effects of cooking, drying and pretreatment methods on texture and starch digestibility of instant rice. J. Food Engineering, 103, 258-264. https://doi.org/10.1016/j.jfoodeng.2010.10.022 
Rhim, J. W. (2002). Kinetics of thermal degradation of anthocyanin pigment solutions driven from red flower cabbage. Food Science and Biotechnology, 11, 361-364.

Rodríguez-Bürger, A. P., Mason, A., \& Nielsen, S. S. (1998). Use of fermented black beans combined with rice to develop a nutritious weaning food. Journal of Agricultural and Food Chemistry, 46, 4806-4813. https://doi.org/10.1021/jf980674h

Saikusa, T., Horino, T, \& Mori, Y. (1994). Distribution of free amino acids in the rice kernel and kernel fractions and the effect of water soaking on the distribution. Journal of Agricultural and Food Chemistry, 42, 1122-1125. https://doi.org/10.1021/jf00041a015

Shih, F. F. (2003). An update on the processing of high-protein rice products. Food, 47, 420-424. https://doi.org/10.1002/food.200390093

Singh, N., Kaur, K., Singh, B., \& Sekhon, K. S. (1999). Effects of phosphate salts on extrusion behavior of rice. Food Chemistry, 64, 481-488. https://doi.org/10.1016/S0308-8146(98)00135-6

Steele, M., Yokum, D., \& Armstrong, A. (1998). Efficacy of intraperitoneal amino acid (IPAA) dialysate in an Asian vegetarian patient with chronic hypoabuminaemia. EDTNA/ERCA Journal, 24, $28-32$.

Sotelo, A., Hernandez, M., Montalvo, I., \& Sousa, V. (1994). Amino acid content and protein biological evaluation of 12 Mexican varieties of rice. Cereal Chemistry, 71, 605-609.

Syafutri, M. I., Pratama, F., Syaiful, F., \& Faizal, A. (2016). Effects of varieties and cooking methods on physical and chemical characteristics of cooked rice. Rice Science, 23, 282-286. https://doi.org/10.1016/ j.rsci.2016.08.006

Tian, Y., Zhao, J., Xie, Z., Wang, J., Xu, X., \& Jin, Z. (2014). Effect of different pressure-soaking treatments on color, texture, morphology and retrogradation properties of cooked rice. LWT-Food Science and Technology, 55, 368-373. https://doi.org/10.1016/j.lwt.2013.09.020

Wallace, T. C., \& Giusti, M. M. (2008). Determination of color, pigment, and phenolic stability in yogurt systems colored with nonacylated anthocyanins from Berberis boliviana L. as compared to other natural/synthetic colorants. Journal of Food Science, 73, C241-C248. https://doi.org/10.1111/j.1750-3841. 2008.00706.x

Walter, M., Marchesan, E., Massoni, P. F. S., da Silva, L. P., Sartori, G. M. S., \& Ferreira, R. B. (2013). Antioxidant properties of rice grains with light brown, red and black pericarp colors and the effect of processing. Food Research International, 50, 698-703. https://doi.org/10.1016/j.foodres.2011.09.002

Wang, L., Hou, G. G., Hsu, Y. H., \& Zhou, L. (2011). Effect of phosphate salts on the Korean non-fried instant noodle quality. Journal of Cereal Science, 54, 506-512. https://doi.org/10.1016/j.jcs.2011.09.008

Wang, W., \& Galili, G. (2016). Transgenic high-lysine rice-a realistic solution to malnutrition? Journal of Experimental Botany, 67, 4009-4011. https://doi.org/10.1093/jxb/erw254

Yuan, S., Chang, S. K. C., Liu, Z., \& Xu, B. (2008). Elimination of trypsin inhibitor activity and beany flavor in soy milk by consecutive blanching and ultrahigh-temperature (UHT) processing. Journal of Agricultural and Food Chemistry, 56, 7957-7963. https://doi.org/10.1021/jf801039h

Xu, B. J., \& Chang, S. K. C. (2007). A comparative study on phenolic profiles and antioxidant activities of legumes as affected by extraction solvents. Journal of Food Science, 72, 159-166. https://doi.org/10.1111/ j.1750-3841.2006.00260.x

Zamindar, N., Baghekhandan, M. S., Nasirpour, A., \& Sheikhzeinoddin, M. (2013). Effect of line, soaking and cooking time on water absorption, texture and splitting of red kidney beans. Journal Food Science and Technology, 50, 108-114. https://doi.org/10.1007/s13197-011-0234-2

\section{Copyrights}

Copyright for this article is retained by the author(s), with first publication rights granted to the journal.

This is an open-access article distributed under the terms and conditions of the Creative Commons Attribution license (http://creativecommons.org/licenses/by/4.0/). 